\title{
A rare cause of aortic valve stenosis: Ochronosis
}

\author{
Aort kapak darlığının nadir bir nedeni: Okronozis \\ Atakan Atalay ${ }^{\circledR}$, Vural Polat ${ }^{1}$ ', Nesrin Turhan ${ }^{2}{ }^{2}$, İrfan Taşoğlu ${ }^{1}$ \\ 'Department of Cardiovascular Surgery, Türkiye Yüksek intisas Training and Research Hospital, Ankara, Turkey \\ 'Department of Pathology, Türkiye Yüksek Intisas Training and Research Hospital, Ankara, Turkey
}

\begin{abstract}
Ochronosis is an autosomal recessive metabolic disorder which may cause aortic valve stenosis. In this article, we report a 58-yearold male patient with alkaptonuria who presented to our institute with severe aortic valve stenosis. He underwent successful aortic valve replacement with a mechanical prosthesis. The deposition of foreign material in valvular tissue is a rare case scenario which may result in serious problems, the management of which may necessitate valve replacement with prosthetic heart valves.
\end{abstract}

Keywords: Alkaptonuria; aortic valve; ochronosis.

Ochronosis is a rare metabolic disorder associated with metabolic deficiency of tyrosine and phenylalanine. Homogentisic acid is accumulated in connective tissue and urine. ${ }^{[1]}$ The usual clinical signs include arthropathy, manifestations affecting the ears, eyes, and skin; genitourinary and cardiovascular complications. Infective endocarditis, Paget's disease, renal failure, drugs, familial hypercholesterolemia, systemic lupus erythematosus, irradiation, and ochronosis are rare causes of aortic stenosis. Incidence of ochronosis ranges between 1:250,000 and 1:1,000,000. ${ }^{[2]}$ The accumulation of homogentisic acid can involve cardiac structures, especially the aorta, coronary vessels, and heart valves. In the elderly, the pericardium may be involved. Pathologic examinations of the aortic valve and ascending aorta have revealed intracellular and extracellular deposits of ochronotic pigments. We report a rare case of alkaptonuria presenting with severe aortic valve stenosis.

\section{$\ddot{O} Z$}

Okronozis, aort kapak darlı̆̆ına neden olabilen bir otozomal resesif metabolik bozukluktur. Bu yazıda, ciddi aort kapak darlığı nedeniyle kliniğimize başvuran alkaptonürisi olan 58 yaşında bir erkek hasta sunuldu. Hastaya mekanik protez ile başarılı aort kapak replasmanı yapıldı. Kapak dokusunda yabancı maddelerin birikimi ciddi sorunlara yol açan nadir durumdur ve yönetimi kalp kapak protezi ile kapak replasmanı gerektirebilir.

Anahtar sözcükler: Alkaptonüri; aort kapağı; okronozis.

\section{CASE REPORT}

A 58-year-old male patient was admitted to our institute with the diagnosis of severe aortic valve stenosis. He had no history of endocarditis or rheumatic fever. His medical history included progressive degenerative arthritis affecting his knees and spine, confirmed by musculoskeletal examination. Results of a general examination included slightly black pigmentation of the sclera of both eyes and the cartilage of the outer ears. His transthoracic echocardiograms confirmed the diagnosis with aortic valve area of $0.5 \mathrm{~cm}^{2}$, mean aortic valve gradient of $65 \mathrm{mmHg}$. Cardiac catheterization revealed normal coronary arteries. The patient underwent surgery to replace his aortic valve. Intraoperatively, it was noted that the aortic valve cusps were tightly stenotic with areas of heavy dark-green calcification impairing the valvular motion (Figure 1). He underwent an aortic valve replacement utilizing a 25-mm mechanical bileaflet valve (St. Jude Medical, Inc., St. Paul, MN, USA).

Received: November 15, 2017 Accepted: February 14, 2018

Correspondence: Atakan Atalay, MD. Türkiye Yüksek Ihtisas Eğitim ve Araştırma Hastanesi, Kalp ve Damar Cerrahisi, 06230 Altındağ, Ankara, Turkey Tel: +90 505 - 3593390 e-mail: atakvc@hotmail.com 


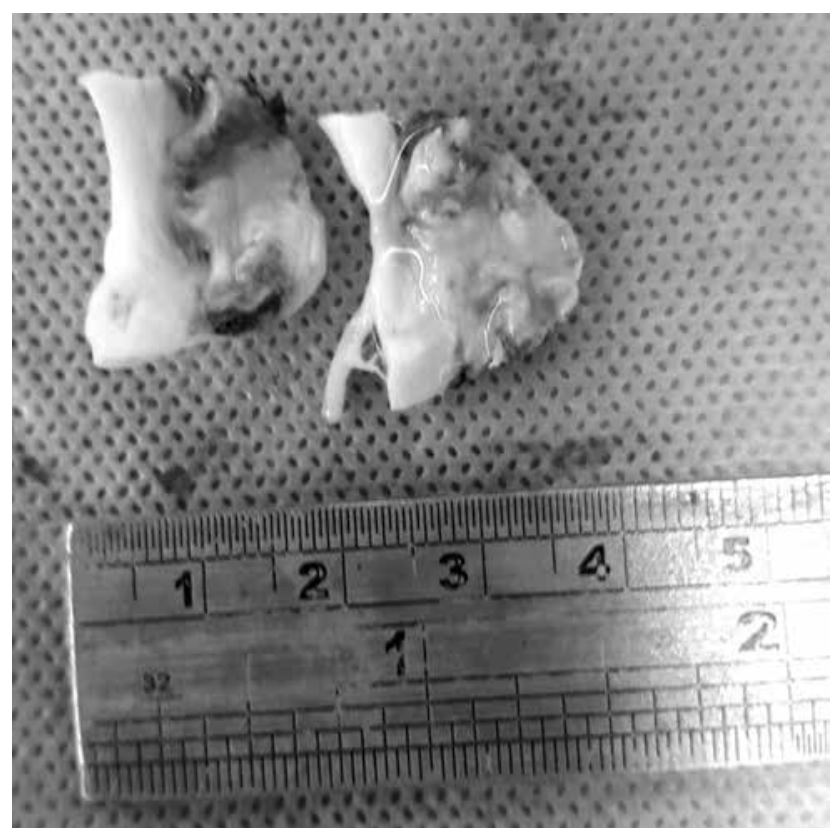

Figure 1. Photograph of operative specimen shows black discoloration of the aortic valve.

The patient recovered uneventfully and he was discharged from the hospital on postoperative day seven. Histopathological examination demonstrated that the valve tissue exhibited calcification, fibromyxoid thickening, and extensive pigmentation. The appearance of the pigment on hematoxylin-eosin stain was gray-brown (Figure 2).

\section{DISCUSSION}

Ochronosis is a rare metabolic disorder associated with a homogentisate 1,2-dioxygenase deficiency. ${ }^{[1]}$ Alkaptonuria mainly affects the musculoskeletal system. The most common complications are spondylosis and arthropathies with impairment of gait and posture. In rare cases, ochronosis can cause valvular heart disease. We diagnosed the disease based on histopathological and clinical findings.

Alkaptonuria is occasionally associated with aortic stenosis but generalized arteriosclerosis and calcification of the heart valves have also been described. $^{[3,4]}$ In general, the severity of the disease progresses after the age of 30 and more rapidly in men than in women.

Generally, the pigment is deposited at the edge and annulus of valves and may lead to degeneration of cells. Other conditions that may have caused valvular heart disease such as age-related calcification of the valves, however our patient had no history of rheumatic fever and endocarditis.

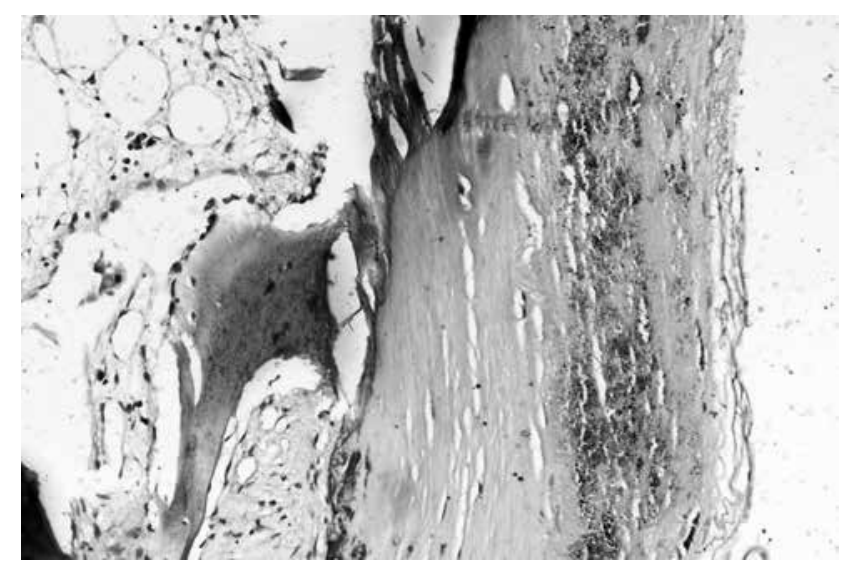

Figure 2. Photomicrograph of a section of valvular leaflet shows ochronotic pigment deposition (H-E×100).

Ochronotic cardiac involvement mainly affects the aortic valve in patients over the age of fifty. In our patient, who was 58 years old, had aortic valve involvement and underwent aortic valve replacement. Over age fifty, involvement of other valves including the mitral and pulmonary valve is common. Although ochronosis is transmitted autosomal recessively, the patient's sister had also undergone heart valve surgery due to ochronotic involvement. Therefore, we believe that family members diagnosed with this disease should also be followed up for heart valve disease.

The optimal choice of valve prosthesis in patients with ochronosis is still under debate and there is a lack of research to guide decision-making in these patients. Previous case reports describe the use of both biological and mechanical devices. Alkaptonuria initially affects the cardiovascular system by pigment deposition. As pigmentation intensity increases, the fibrolipid components of atheromatous plaques are affected by degeneration of pigment-laden fibrocytes. Extensive extracellular deposition of pigment occurs in the cusps and valve annulus, which serve as a stimulus for dystrophic and accelerated calcification. Pigment deposition and calcification may accelerate degeneration of the bioprosthetic valve. Gaines and $\mathrm{Pai}^{[5]}$ suggested that ochronotic pigment in the aortic valve serves as a stimulus for dystrophic calcification that eventually leads to aortic valve stenosis. Considering the pathophysiology of ochronotic heart valvular disease, the biological valve prosthesis may be exposed to the same process of homogentisic acid deposition and calcification as is native valve tissue, thus adversely affecting longevity of the bioprosthesis. In light of these findings, we believe that mechanical valve replacement is an ideal choice in patients affected with ochronosis. 
Cardiac ochronosis is a very rare disease that has a good outcome after surgical intervention. We conclude that, in the short term, either a mechanical or a biological prosthesis is a reasonable option for aortic valve replacement in patients with aortic stenosis secondary to alkaptonuria. Long-term broad-range results are not available because of the rarity of the disease. We would advocate the use of a mechanical prosthesis until that time.

\section{Declaration of conflicting interests}

The authors declared no conflicts of interest with respect to the authorship and/or publication of this article.

\section{Funding}

The authors received no financial support for the research and/or authorship of this article.

\section{REFERENCES}

1. Phornphutkul C, Introne WJ, Perry MB, Bernardini I, Murphey MD, Fitzpatrick DL, et al. Natural history of alkaptonuria. N Engl J Med 2002;347:2111-21.

2. La Du BN. Alkaptonuria. In: Scriver CR, Beandet AL, Sly WS, Valle D, editors. Metabolic \& Molecular Basis of Inherited Diseases. 8th ed. New York: McGraw-Hill; 2001. p. 2109-23.

3. Karavaggelis A, Young C, Attia R. Black heart at surgeryprimary diagnosis of alkaptonuria at surgery. J Cardiol Curr Res 2017;9:00336.

4. Atalay A, Gocen U, Basturk Y, Kozanoglu E, Yaliniz H. Ochronotic involvement of the aortic and mitral valves in a 72-year-old man. Tex Heart Inst J 2015;42:84-6.

5. Gaines JJ Jr, Pai GM. Cardiovascular ochronosis. Arch Pathol Lab Med 1987;111:991-4. 